\title{
Preliminary Proteomic Analysis of Indomethacin's Effect on Tumor Transplanted with Colorectal Cancer Cell in Nude Mice
}

\author{
Yu-Jie Wang ${ }^{1}$, Gui-Ying Zhang, ${ }^{1, *}$, Zhi-Qiang Xiao' ${ }^{2}$ Hong-Mei Wang' and Zhu-Chu Chen ${ }^{2}$ \\ ${ }^{1}$ Department of Gastroenterology, Xiangya Hospital of Central South University, Changsha, Hunan, Zip code: 410008, P. R. China \\ ${ }^{2}$ Key Laboratory of Cancer Proteomics of Chinese Ministry of Health, Xiangya Hospital, Central South University, \\ Changsha, Hunan, Zip code: 410008 , P. R. China
}

Received 10 November 2005, Accepted 12 December 2005

\begin{abstract}
Nonsteroidal anti-inflammatory drugs such as indomethacin (IN) can exert anti-colorectal cancer (CRC) activity through cyclooxygenase independent mechanism, but the exactly biological mechanism is not completely known. Here we use proteomic tools to investigate the molecular mechanism of this action. First, nude mice bearing tumors derived from subcutaneous injection with human CRC cell line HCT116 were randomly allocated to groups treated with or without indomethacin. Later, tumor lumps were incised and then total proteins extracted. After separated with two-dimensional electrophoresis, thirty-one differently expressed spots were found between IN-treated and nonIN-treated groups, of which 25 spots decreased and 6 spots increased in abundance in IN-treated group. Through matrix-assisted laser desorption ionization time of flight mass spectrometry and then NCBInr and SWISS-PROT databases searching, 12 protein spots were finally identified including galectin-1, annexin A1, annexin IV, trancription factor BTF3A, calreticulin. Most of the identified proteins are correlated with tumor's biological prosperities of proliferation, invasion, apoptosis and immunity, or take part in cell's signal transduction. From above we thought that indomethacin can exert its effect on colorectal cancer through regulating several proteins' expression directly or indirectly. Further study of these proteins may be helpful in founding new targets of drugs for cancer chemotherapy.
\end{abstract}

Keywords: Colorectal cancer, Indomethacin, Matrix assisted laser desorption/ionization-mass spectrometry, Two-dimensional gel electrophoresis

\footnotetext{
*To whom correspondence should be addressed. Tel: 86-731-4327282; Fax: 86-731-4327332

E-mail: zhangguiying@yeah.net
}

\section{Introduction}

Colorectal cancer is among the leading causes of cancerrelated mortality, and the search for effective drugs to the therapy, or those with potential to prevent colorectal cancer, is of great importance. Because chronic inflammation is a critical component of tumor progression (Coussens and Werb, 2002), nonsteroidal anti-inflammatory drugs (NSAIDs), as the main anti-inflammation drugs, draw more and more research attention for their functions of cancer therapy and chemoprevention. Regular intake of NSAIDs, including indomethacin, is associated with decreased incidence of colorectal adenoma or colorectal cancer (Garcia-Rodrigez and Huerta-Alvarez, 2000). Accumulated animal model experiments and population-based investigations have also shown a protective effect of these drugs against neoplasia in many other sites of the body beside colon, such as esophagus (Sonnenberg and Fennerty, 2003), stomach (Sawaoka et al., 1998), lung (Hida et al., 1998), breast (Kundu1 et al., 2002), head and neck (Pelzmann et al., 2004), this suggests a common mechanism of NSAIDs' effect in these different cancer sites. Indomethacin has been frequently used to study the effect on colorectal cancer as well as cancers in other sites since Waddell et al found that indomethacin could cause rectal polyps regressed in Gardner's syndrome patients with desmoid tumors (Waddell and Gerner, 1980). Subsequent studies of its effect on skin, head and neck cancers showed its direct anti-neoplastic activity (Al-Saleem et al., 1980; Panje, 1981). A population-based cohort study with a secondary case-control analysis indicated that the relative risk of having either colorectal cancer or adenoma in current users of indomethacin was 0.4 compared with NSAIDs non-users (Garcia-Rodrigez and Huerta-Alvarez, 2000). Indomethacin also displayed prosperities of prolonging mean survival of colorectal cancer patients illuminated by a randomized, placebo-controlled trial (Lundholm et al., 1994).

Despite lots of researches related to indomethacin's effect 
on CRC, concrete mechanism of its anti-tumor activity is not completely known. Cyclooxygenase-2 (COX-2) has been thought to play a pivotal role in this process, because colorectal adenoma and adenocarcinoma have high level expression of COX-2 (Eberhart et al., 1994), and COX-2 inhibiting drugs such as celecoxib can impede cancer proliferation (Williams et al., 2000). However, other evidences exhibited that COX-independent cancer-chemotherapy mechanisms of NSAIDs still exist, because NSAIDs had antiproliferative effects on cell lines which do not expressed COX (Hanif et al., 1996; Zhang et al., 1999). Indomethacin can inhibit tumor growth in either HT29, HCA-7, which are COX-2 positive cancer cell lines, or SW480 and HCT116, which are COX-2 negative (Smith et al., 2000). Several studies have demonstrated that NSAIDs including indomethcin can play a chemopreventive and therapeutic activity through targets such as ribosomal S6 kinase 2 (RSK2) (Stevenson et al., 1999) and peroxisome proliferator-activated receptor $\delta$ (PPAR $\delta$ ) (He et al., 1999). Since the development of colorectal cancer results from the accumulated genetic alterations rather than from any single one (Kinzler and Vogelstein, 1998), NSAIDs may exert their chemoprevention and therapeutic activity through other unknown ways. Proteomics provide a high throughout method to study the complexity of life. In previous study, we found from in vivo experiment that oral administration of indomethacin $(3 \mathrm{mg} / \mathrm{kg} \cdot \mathrm{d})$ significantly suppressed tumor growth of the HCT116 xenografts in BALB/c-nu/nu mice (Wang and Zhang, 2005). Here we use proteomic tools to analysis the mechanism of indomethacin's effects on xenograft nude mice generated with colorectal cancer cell line HCT116.

\section{Materials and Method}

IPGphor, Ettan DALT II System, ImageScanner (maximum resolution 9,600×9,600 dpi) (Amersham Biosciences, Stockholm, Sweden), Voyager-DE STR MALDI-TOF Mass Spectrometry (Applied Biosystems), PDQuest system (Bio-Rad laboratories), Mascot Distiller, Mascot Database Search engine and Statistical Package For Social Science (SPSS for windows, Version 10.01, USA) were used. Indomethacin and dimethyl sulfoxide (DMSO) were purchased from Sigma Chemical Corporation (USA). Thiourea, urea, dithiothreitol, cholamidopropyl-dimethyl ammoniopropane sulfonate (CHAPS), bromophenol blue, Pharmalyte ( $\mathrm{pH}$ 310), Acrylamide, bis-acrylamide, tetramethylethylenediamine (TEMED), low-molecular-weight protein marker, glycine, Trisbase, sodium dodecyl sulfate (SDS), immobiline $\mathrm{pH}$-gradient DryStrips (pH 3-10, $24 \mathrm{~cm}$ ), IPG buffer (pH 3-10) and DryStrip cover fluids were obtained from Amersham Pharmacia Biotech. Commassie brilliant blue G-250, mercaptoethanol, iodoacetamide, hydrochloric acid (HCL), and 37\% v/v formaldehyde were from Sigma. Acetic acid, glycerol, methanol, sodium thiosulfate, and sodium carbonate were from Fisher Scientific (Pittsburgh). All buffers were prepared with Milli-Q water.
Samples preparation. Samples preparation was followed with our previous study, briefly, after the IC50 of indomethacin's antiproliferative activity was accepted, approximately $1.0 \times 10^{7}$ HCT116 cells in $0.2 \mathrm{~mL}$ serum-free medium were implanted subcutaneously into the right flank of each BALB/c-nu/nu mouse (Experimental Animal Center of Shanghai). First, xenografts were allowed to grow up to $4-5 \mathrm{~mm}$ in diameter, then the mice were randomly distributed into non-indomethacin-treated group administrated with drug vehicle $(5 \mathrm{~mL} / \mathrm{L}$ DMSO) by gavage or indomethacin-treated group with indomethacin $(3 \mathrm{mg} / \mathrm{kg} \cdot \mathrm{d}$ in $5 \mathrm{~mL} / \mathrm{L} \mathrm{DMSO})$. Tumor size was measured every other day. Twenty-seven days after initiation of drug treatment, the mice were sacrificed and part of the tumors was removed, flushed out of blood and immediately snapfrozen in liquid nitrogen until analysis. Finally, tissues were grounded into powder with liquid nitrogen present in mortar and 50 $\mathrm{mg}$ powder was lysed in $400 \mu \mathrm{l}$ lysis buffer $(7 \mathrm{~mol} / \mathrm{L}$ urea, $2 \mathrm{~mol} / \mathrm{L}$ thiourea, $100 \mathrm{mmol} / \mathrm{L}$ DTT, $4 \%$ CHAPS, $40 \mathrm{mmol} / \mathrm{L}$ Tris-base, $2 \%$ pharmalyte), The lysates were incubated at $37^{\circ} \mathrm{C}$ for 1 our and centrifuged at $15,000 \mathrm{rpm}$ at $4^{\circ} \mathrm{C}$ for $45 \mathrm{~min}$. The supernatant was removed, divided into several aliquots and stored at $-80^{\circ} \mathrm{C}$ until further experiment. The concentration of the total proteins was determined with the 2D Quantification kit (Amersham Biosciences).

Two-dimensional gel electrophoresis. Two-DE was performed as recommended by the manufacturer (Amersham Biosciences). For first-dimension isoelectric focusing (IEF) electrophoresis, 1mg protein sample diluted with resolubilized solution ( $8 \mathrm{M}$ urea, 20 mM DTT, 2\% CHAPS, trace bromophenol blue and $0.5 \%$ IPG buffer $\mathrm{pH} 3-10$ ) to a total volume of $450 \mu \mathrm{L}$ was adsorbed onto 24 $\mathrm{cm}$ immobilized $\mathrm{pH}$ 3-10 nonlinear gradient (IPG) strips at $20^{\circ} \mathrm{C}$ for $14 \mathrm{~h}$, and then focused on an IPGphor IEF unit by using a step-wise increasing voltage $(100 \mathrm{~V}$ for $1 \mathrm{~h}, 500 \mathrm{~V}$ for $1 \mathrm{~h}, 1000 \mathrm{~V}$ for $1 \mathrm{~h}$, and $8,000 \mathrm{~V}$ for $10 \mathrm{~h}$ ). Prior to the second dimension, each strip was equilibrated for $10 \mathrm{~min}$ in equilibration buffer A (6 M urea, $2 \%$ SDS, 30\% glycerol, $22 \mathrm{mM}$ DTT, trace bromophenol blue and 50 $\mathrm{mM}$ Tris-HCL, $\mathrm{pH} 8.8$ ) and B (6 M urea, $2 \%$ SDS, $30 \%$ glycerol, $135 \mathrm{mM}$ idioacetamide, trace bromophenol blue and $50 \mathrm{mM}$ TrisHCL, pH 8.8), respectively. After equilibration, strips were sealed on a vertical $250 \times 185 \times 1 \mathrm{~mm}$ SDS separating gels $(12 \% \mathrm{~T} ; 1.6 \%$ C) with a $0.8 \%$ agarose dissolved in $0.1 \%$ SDS and $125 \mathrm{mM}$ TrisHCL, $\mathrm{pH}$ 8.8. Low-molecular-weight protein markers were prepared in the same material and dispensed in $1 \mathrm{~mm} \times 4 \mathrm{~mm}$ plugs. Then, the plugs were sealed in place with $0.8 \%$ agarose. Electrophoresis separation was performed at the constant power pattern $(2.5 \mathrm{~W}$ for $0.5 \mathrm{~h}, 12 \mathrm{~W}$ for $6 \mathrm{~h}$ ) on Ettan DALT system. Each experiment was performed in duplicate.

Protein staining and image analysis. After electrophoresis, the modified Neuhoff's colloidal Coomassie Blue G-250 staining method was used to visualize the protein spots in the 2-DE gels (Candiano1 et al., 2004). Destaining was performed in ultra pure water until the background was completely clear. Two-DE maps were obtained by scanning the gels using the Imagescanner. Analysis of the gels was accomplished using the PDQuest analysis software including background subtraction, spots detection, volume normalization and the establishment of a reference gel. Average gels were matched to the reference gel, a virtual gel which 
containing all spots detected on any gel, and the average gels derived from IN-treated and non-IN-treated groups were compared. Intensity of each spot was quantified by calculation of spot volume after normalization of the image using the total spot volume normalization method multiplied by the total area of all the spots. Statistical analysis was carried out with SPSS for Windows 10.01 and Excel. Average gels from at least three independent experiment were compared to each other and spots having statistic difference $(p<0.05)$ in intensity were selected for further identification by MALDI-TOF-MS.

In-gel digestion. Differently expressed protein spots between the two groups were excised manually from stained two-DE gels, transferred to a $1.5 \mathrm{~mL}$ Eppendorf tube, and rinsed three times with ultra pure water. Spots were destained in $50 \mu \mathrm{L} 50 \%$ acetonitrile (ACN) estaining solution at $37^{\circ} \mathrm{C}$ for $30 \mathrm{~min}$ followed by dehydration in $30 \mu \mathrm{L} \mathrm{ACN}$ until gel pieces were white and hard. Then the gel pieces were dried thoroughly in a vacuum centrifuge for about $50 \mathrm{~min}$. The dried gel pieces were reconstituted with $5 \mu 150 \mathrm{mmol}$ $\mathrm{NH}_{4} \mathrm{HCO}_{3}$ containing $100 \mu \mathrm{g} / \mathrm{mL}$ trypsin (Promega, Madison, WI, USA) and the in-gel digestion was continued for 14 to $16 \mathrm{~h}$ at $37^{\circ} \mathrm{C}$. Peptides extraction was performed with $30 \mu \mathrm{l}$ solution consisting of $50 \% \mathrm{ACN}$ and $2.5 \%$ trifluoroacetic acid (TFA) and condensed in vacuum centrifuge to no more than $5 \mu$ l of terminal volume.

Protein identification using MALDI-TOF-MS. Extracted peptide samples were prepared using $\alpha$-cyano-4-hydroxycinnamic acid as the MALDI-TOF matrix. The matrix solution was saturated in $50 \%$ ACN, $0.1 \%$ TFA. The peptide solution $(0.5 \mu \mathrm{L})$ was applied first to the sample plate target, then matrix solution $(0.5 \mu \mathrm{L})$ was added on the plate target mixed with the peptide solution. After the samples were air-evaporated, MALDI-TOF-MS was performed on a VoyageDE STR MALDI-TOF Mass Spectrometer. The parameters of MALDI-TOF were set up as follows: accelerating voltage, $20 \mathrm{kV}$; grid voltage $64.5 \%$; delay $100 \mathrm{~ns}$; the number of laser shots 100 and the acquisition mass range $900 \mathrm{Da}-3,500 \mathrm{Da}$. The spectra were internally calibrated using two peptides arising from trypsin autoproteolysis $\left([\mathrm{M}+\mathrm{H}]^{+}\right.$842.5100; $\left.[\mathrm{M}+\mathrm{H}]^{+} 2211.1046\right)$. Peptide mass fingerprintings (PMF) obtained in the positive ion reflector mode in Monoisotopic peptide masses were searched in the NCBI or SWISS-PROT database using Mascot software (http://www. matrixscience.com) with the following parameters: all entries, one missed cleavage site and a mass tolerance setting of $200 \mathrm{ppm}$. Carbomidomethylation of cysteine and oxidation of methionine were considered as fixed modification or possible partial modification. The probability scores calculated by software were used as criterion for correct identification.

\section{Results}

The tumor volume of treated group $\left(459 \pm 32 \mathrm{~mm}^{3}\right)$ was significantly decreased compared to the control group $\left(828 \pm 32 \mathrm{~mm}^{3}\right) \quad(p<0.05)$, as displayed in our previous research (Wang and Zhang, 2005), suggested that oral administration of indomethacin $(3 \mathrm{mg} / \mathrm{kg} \cdot \mathrm{d})$ can significantly suppress tumor growth of the HCT116 xenografts. Total tissue

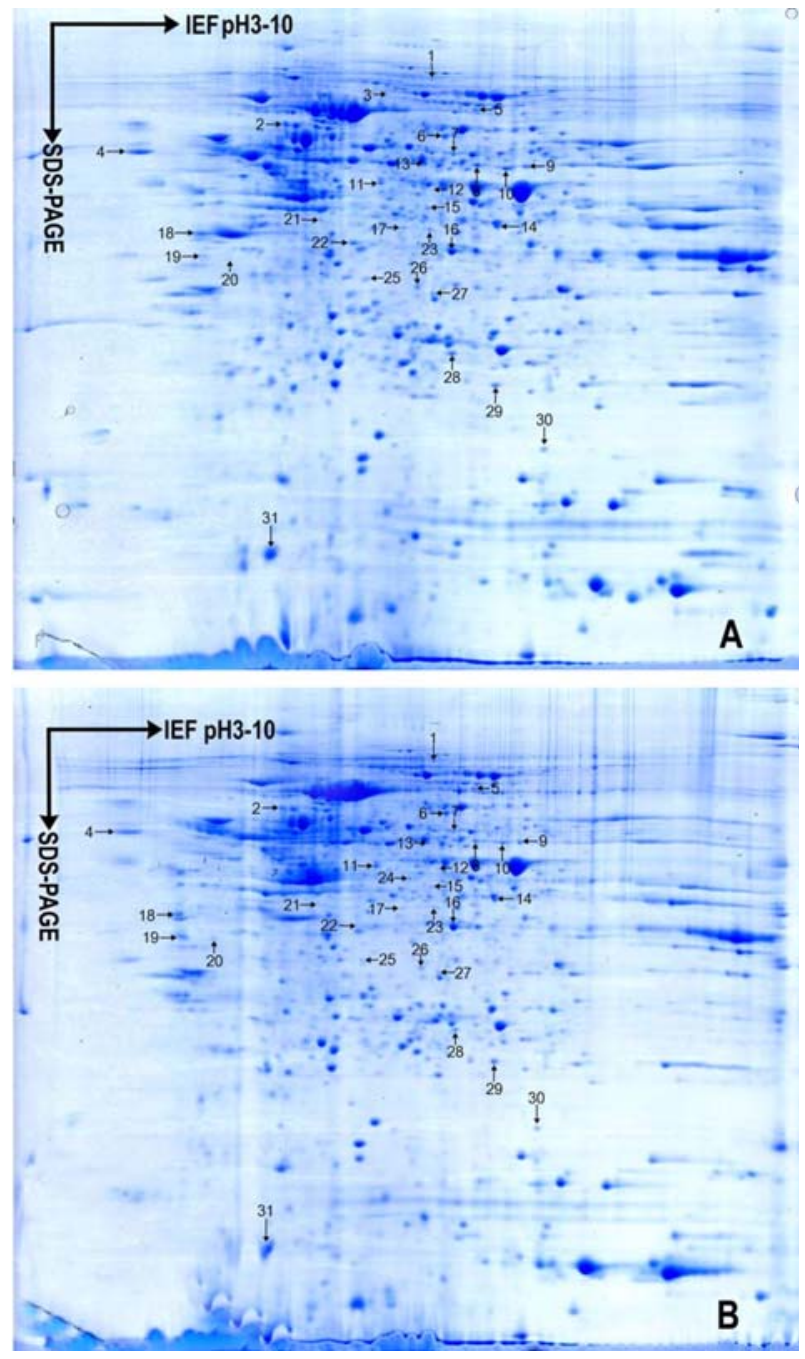

Fig. 1. Two-dimensional electrophoresis maps of $1 \mathrm{mg}$ proteins extracted from tumors of xeograft nude mice treated without indomethacin (A) or with indomethacin (B). The gels were stained with the modified Neuhoff's colloidal Coomassie Blue G-250 staining method.

protein extracts of the tumors removed from IN-treated and non-IN-treated mice were separated by proteomic tools. The sensibility of Coomassie Blue G-250 staining method is lower than silver stain, but the loading amount of the former is higher than of the latter, and Coomassie Blue staining is well compatible with mass spectrometry. The gels were loaded with $1 \mathrm{mg}$ of protein sample and stained with the modified Neuhoff's colloidal Coomassie Blue G-250 staining method (Candiano et al., 2004). Two-DE maps were obtained as representative ones depicted in Fig. 1A and B. Other two pairs of replicas of the treated and control groups were perfectly superimposed, demonstrating that the reproducibility of the test was good. Using PDQuest 2-DE gels analysis software, approximately 1100 well-stained, clearly-delineated protein spots were detected, most spots were distributed between $\mathrm{pH}$ 5 to $\mathrm{pH} 8$ area. Thirty one spots which showed remarkable 


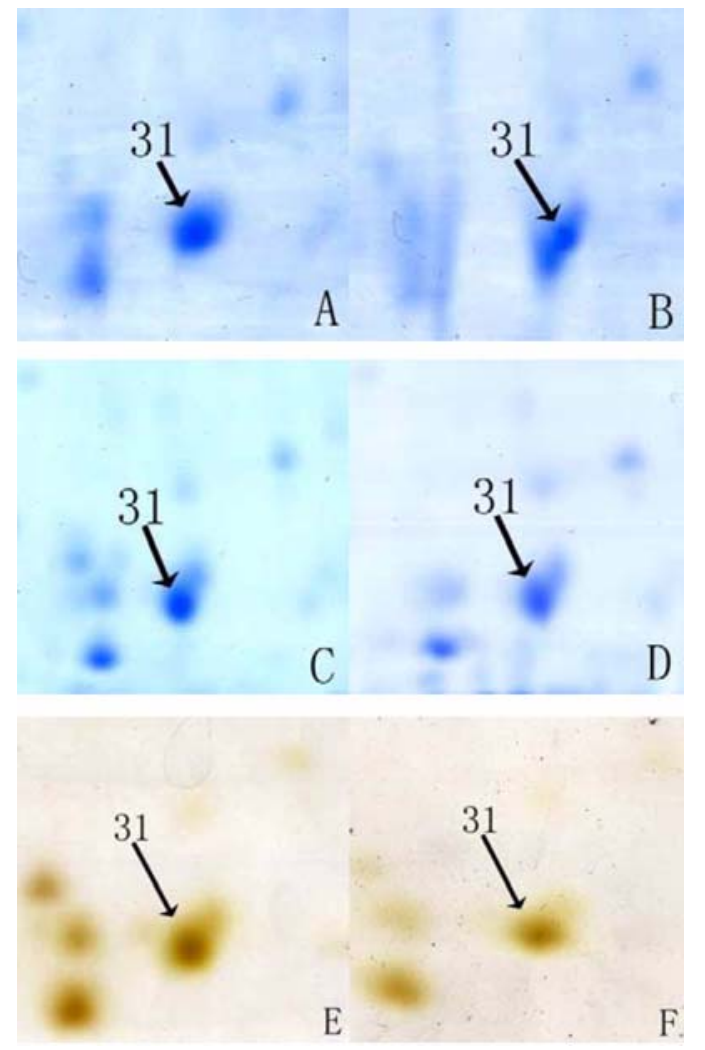

Fig. 2. Differential expression of protein spot 31 between nonindomethacin treated groups (Fig. A, C and E) and indomethacin treated groups (Fig. B, D and F), the protein expression level of spot 31 was down-regulated in indomethacin treated group.

change $(p<0.05)$ between IN-treated groups and non-INtreated groups had been observed, of which 25 pots were down regulated and 6 spots up regulated. These differentially expressed protein spots are illustrated with arrows in Fig. 1. Differently expressed spots were excised from one single gel, or from two to four gels and analyzed for protein identification by MALDI-TOF-MS. With MALDI-TOF-MS 20 peptide mass finger prints (PMF) were successfully obtained. A selected PMF of protein spot 31 was displayed in Fig. 3. All PMFs were searched with Mascot software in NCBInr or SWISS-PROT database to identify the protein spots. The result had high confidence if the protein was ranked as the best hit with a significant score and high sequence coverage. Figure 4 shows an example of searching result for protein spot 31 (this spot was identified to be galectin-1, with the top score of 105 and sequence coverage of $62 \%$ ). Finally, we identified 12 proteins in those spots, which are showed in Table 1.

\section{Discussion}

More and more studies show evidences that NSAIDs have chemoprevention and antiproliferative activity against cancer. Indomethacin is also among these drugs studied. Our previous

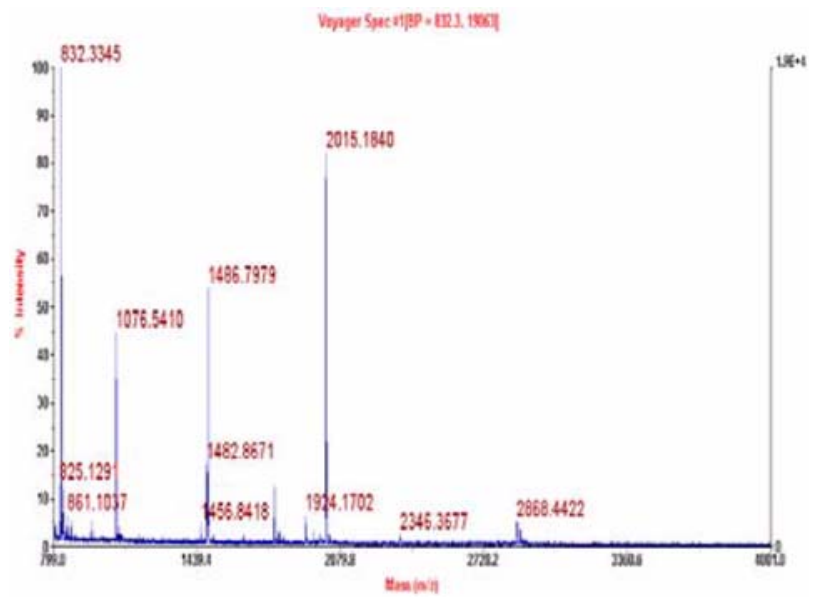

Fig. 3. Peptide mass finger print of protein spot 31 (galectin-1) obtained from MALDI-TOF-MS.

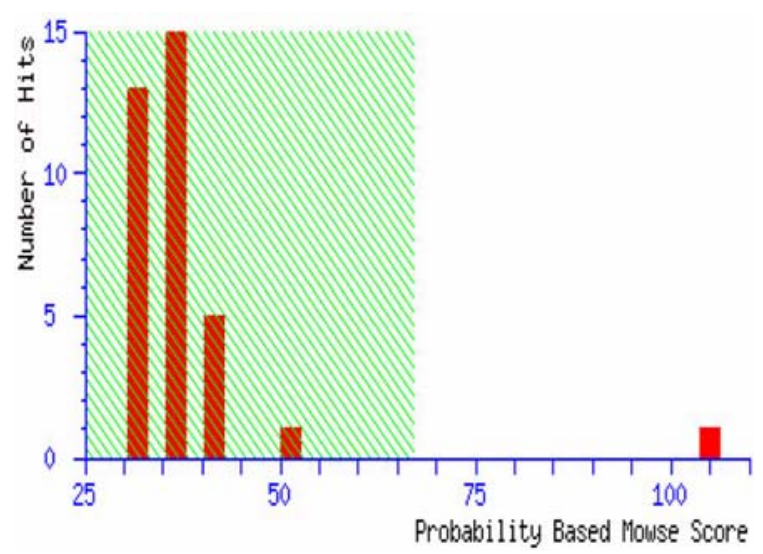

Fig. 4. Database searching result and score of protein spot 31 with Mascort software, Ions score is $-10^{*} \log (\mathrm{P})$, where $\mathrm{P}$ is the probability that the observed match is a random event. Protein score greater than 67 is significant $(p<0.05)$.

studies have shown that indomethacin has antiproliferative activity on xenograft of HCT116 in nude mice. To investigate the underlying mechanisms by which indomethacin exerts its effects on colon cancer, we used proteomic tools here in order to find protein targets of indomethacin interfering with colon cancer. In this proteomic study, the 2-DE profiles of proteins extracted from tumor of IN-treated and non-IN-treated xenograft nude mice were analyzed and compared with each other. As shown in Fig. 1, we separated about 1,100 protein spots in the gel and found 31 differently expressed protein spots. With mass spectrum 12 of those differently expressed protein spots were identified, as showed in Table 1. Most of these identified proteins are correlated with tumor's biological prosperities, such as proliferation, invasion, apoptosis and immunity, or take part in cell's signal transduction. For indomethacin' effects on colon cancer, these proteins might give some insight into the COX-independent molecular mechanism. 
Table 1. Searching results of differently expressed proteins in IN-treated and non-IN-treated group

\begin{tabular}{|c|c|c|c|c|c|c|c|c|c|c|}
\hline $\begin{array}{l}\text { Spot } \\
\text { No }\end{array}$ & $\begin{array}{l}\text { Accession } \\
\text { ID }\end{array}$ & $\begin{array}{l}\text { Top } \\
\text { Score }\end{array}$ & $\begin{array}{l}\text { Sequence } \\
\text { coverage }\end{array}$ & $\begin{array}{l}\mathrm{Mr} \\
(\mathrm{Da})\end{array}$ & $\begin{array}{c}\text { Theoretical } \\
\text { pI }\end{array}$ & protein name & $\begin{array}{c}\text { Density } \\
\text { volume } \\
\text { (non-IN- } \\
\text { treated) }\end{array}$ & $\begin{array}{c}\text { Density } \\
\text { volume } \\
\text { (IN-treated) }\end{array}$ & $P$ value & $\begin{array}{l}\text { Expression in } \\
\text { IN-treated groups }\end{array}$ \\
\hline 4 & gi|4757900 & 83 & $40 \%$ & 48283 & 4.29 & calreticulin precursor & $3195 \pm 247$ & $2222 \pm 164$ & 0.030 & Down regulated \\
\hline 6 & gi $\mid 4502643$ & 226 & $73 \%$ & 58444 & 6.23 & $\begin{array}{l}\text { chaperonin containing } \\
\text { TCP1, subunit } 6 \mathrm{~A}\end{array}$ & $658 \pm 79$ & $1104 \pm 62$ & 0.011 & Up regulated \\
\hline 7 & gi|15030035 & 99 & $42 \%$ & 57370 & 6.29 & $\begin{array}{c}\text { Phosphoglycerate } \\
\text { dehydrogenase }\end{array}$ & $294 \pm 8$ & $152 \pm 42$ & 0.046 & Down regulated \\
\hline 8 & gi|13623415 & 149 & $46 \%$ & 55151 & 6.84 & Fascin 1 & $627 \pm 17$ & $473 \pm 39$ & 0.005 & Down regulated \\
\hline 11 & P10809 & 102 & $35 \%$ & 61016 & 5.70 & $\begin{array}{l}60 \mathrm{kDa} \text { heat } \\
\text { shock protein }\end{array}$ & $237 \pm 21$ & $286 \pm 18$ & 0.035 & Up regulated \\
\hline 14 & gi|4885063 & 125 & $69 \%$ & 39830 & 6.41 & $\begin{array}{c}\text { Aldolase C, } \\
\text { fructose-bisphosphate }\end{array}$ & $551 \pm 26$ & $436 \pm 33$ & 0.049 & Down regulated \\
\hline 15 & gi|40788885 & 88 & $53 \%$ & 42348 & 6.05 & KIAA0158 & $333 \pm 49$ & $142 \pm 27$ & 0.027 & Down regulated \\
\hline 16 & gi|54696696 & 124 & $63 \%$ & 38918 & 6.57 & annexin $\mathrm{A} 1$ & $1882 \pm 72$ & $1469 \pm 120$ & 0.042 & Down regulated \\
\hline 25 & A42077 & 192 & $58 \%$ & 36290 & 5.84 & annexin IV & $343 \pm 32$ & $192 \pm 13$ & 0.012 & Down regulated \\
\hline 26 & Q8WVX0 & 86 & $36 \%$ & 36078 & 8.47 & ECH1 protein & $321 \pm 7$ & $246 \pm 14$ & 0.010 & Down regulated \\
\hline 30 & gi|107909 & 83 & $53 \%$ & 22212 & 9.24 & $\begin{array}{l}\text { transcription } \\
\text { factor BTF3a }\end{array}$ & $451 \pm 48$ & $175 \pm 23$ & 0.007 & Down regulated \\
\hline 31 & gi|42542977 & 105 & $62 \%$ & 14868 & 5.34 & Galectin-1 & $3465 \pm 528$ & $972 \pm 69$ & 0.009 & Down regulated \\
\hline
\end{tabular}

Galectins belong to a protein family of soluble lactosebinding lectins characterized by their affinity to beta galactoside moieties and by conserved sequence elements in their carbohydrate recognition domains (Barondes et al., 1994a; Barondes et al., 1994b). Galectins can be detected in a variety of tissues, suggesting that they might mediate a wide range of biological functions (Rabinovich et al., 2002). They involve in lots of important biological process such as regulating interaction between cells or cell and matrix. They are associated with tumor's biological prosperities of proliferation, invasion, apoptosis and local immunity as well. Galectins interact with the extracellular glycans of cell-surface components including laminins, fibronectins and integrins (Yang and Liu, 2003). While most glycans are located outside cells where cell-cell or cell-matrix interactions occur, this suggests that galectins may be attractive targets for the development of new therapeutic strategies (Lahm et al., 2001; Liu et al., 2002). Galectin-1, an important member of the beta galactoside-binding galectin protein family, is a homodimeric protein with a carbohydrate recognition domain of 134 amino acids (Barondes et al., 1994a). Exogenous administration of human recombinant galectin-1 suggested galectin-1 play key role in a variety of biological events involving cell-cell and cell-extracellular matrix interactions, cell growth regulation, metastasis, and immunomodulation (Perillo et al., 1998). Galectin-1 can bind to CD45 molecules present on the lymphocyte surface, thus might implicate its role in the induction of apoptosis of activated T cells (Perillo et al., 1995). Galectin-1 present either at the surface of cancer cells or in their close neighborhood, It could protect them against a T-cell immune response and constitute an advantage for survival. Blockade of immunosuppressive galectin-1 in vivo promotes tumor rejection and stimulates the generation of a tumor-specific $\mathrm{T}$ cell-mediated response in syngeneic mice, which are then able to resist subsequent challenge with wild-type galectin-1 sufficient tumors (Rubinstein et al., 2004). Normal colorectal mucosa has a weak galectin-1 expression in both the epithelial and the stromal components. Its expression in stroma showed a progressive overexpression from normal mucosa to adenomas and to carcinomas (Sanjuan et al., 1997). In our study, usage of indomethacin can down-regulate expression level of galectin-1 in colorectal cancer, suggesting that the antiproliferative activity of indomethacin against colorectal cancer might be related to its interaction with galectin-1 directly or indirectly.

Apoptosis, also termed programmed cell death, is an important capability on which living organizations depend to eliminate defective or surplus cells through the activation of evolutionary conserved intracellular pathway leading to pathognomonic cellular changes. Inappropriate apoptosis destroy the balance between cell proliferation and cell death and thus participate in the development of cancer. Several gene products involved in the process of apoptosis, such as p53, bcl-2, TGF-beta1. Polymerase B transcription factor 3 (BTF3) had been identified associated with anti-IgM antibody mediated apoptosis in the human Burkitt lymphoma cell line BL60 as the BTF3 protein is significantly decreased in intensity compared with the pattern of nonapoptotic cells (Brockstedt et al., 1999). In our study, BTF3a is down regulated in IN-treated groups compared with non-IN-treated groups, suggesting that indomethacin may exert its action on colon cancer through regulating the expression of BTF3.

Besides galectin-1 and BTF3a, other differentially expressed proteins found in this study, such as annexin A1 and 
calreticulin, are also closely pertinent to the biological properties of tumors. Due to the difficulty of displaying low abundance proteins by general proteomic methods, we did not find those proteins which were found related with indomethacin's effects on colon cancer by other researchers, for example PPAR $\delta$ and catenin. Another reason for this problem is that the impact of indomethacin on colorectal cancer may be relevant not only to the quantitative alteration of protein expression, but also to the post-transcriptional modification.

From above we thought that indomethacin can exert its effect on colorectal cancer through regulating several proteins' expression directly or indirectly. Further study of these proteins may be helpful in founding new targets of drugs for cancer chemotherapy.

Acknowledgments This work was supported by Natural Science foundation of P. R. China (No. 30271516).

\section{References}

Al-Saleem, T., Sabri, A. Z. and Qassab, M. (1980) Skin cancers in xeroderma pigmentosum: response to indomethacin and steroids. Lancet 2, 264-265.

Barondes, S. H., Castronovo, V., Cooper, D. N., Cummings, R. D., Drickamer, K., Feizi, T., Gitt, M. A., Hirabayashi, J., Hughes, C. and Kasai, K. (1994a) Galectins: A family of animal beta-galactoside-binding lectins. Cell 76, 597-598.

Barondes, S. H., Cooper, D. N. W., Gitt, M. A. and Leffler, H. (1994b) Galectins: Structure and function of a large family of animal lectins. J. Biol. Chem. 269, 20807-20810.

Brockstedt, E., Otto, A., Rickers, A., Bommert, K. and WittmannLiebold, B. (1999) Preparative high-resolution two-dimensional electrophoresis enables the identification of RNA polymerase B transcription factor 3 as an apoptosis-associated protein in the human BL60-2 Burkitt lymphoma cell line. J. Protein Chem. 18, 225-231.

Candiano, G., Bruschi, M., Musante, L., Santucci, L., Ghiggeri, G. M., Carnemolla, B., Orecchia, P., Zardi, L. and Righetti, P. G. (2004) Blue silver: A very sensitive colloidal Coomassie G-250 staining for proteome analysis. Electrophoresis 25, 1327-1333.

Coussens, L. M. and Werb, Z. (2002) Inflammation and cancer. Nature 420, 19-26.

Eberhart, C. E., Coffey, R. J., Radhika, A., Giardiello, F. M., Ferrenbach, S. and DuBois, R. N. (1994) Up-regulation of cyclooxygenase 2 gene expression in human colorectal adenomas and adenocarcinomas. Gastroenterology 107, 11831188.

Garcia-Rodrigez, L. A. and Huerta-Alvarez, C. (2000) Reduced incidence of colorectal adenoma among long-term users of nonsteroidal anti-inflammatory drugs: A pooled analysis of published studies and a new population-based study. Epidemiology 11, 376-381.

Hanif, R., Pittas, A., Feng, Y., Koutsos, M. I., Qiao, L., StaianoCoico, L., Shiff, S. I. and Rigas B. (1996) Effects of nonsteroidal anti-inflammatory drugs on proliferation and on induction of apoptosis in colon cancer cells by a prostaglandin- independent pathway. Biochem. Pharmacol. 52, 237-245.

He, T. C., Chan, T. A., Vogelstein, B. and Kinzler, K. W. (1999) PPAR delta is an APC-regulated target of nonsteroidal antiinflammatory drugs. Cell 99, 335-345.

Hida, T., Leyton, J., Makheja, A. N., Ben-Av, P., Hla, T., Martinez, A., Mulshine, J., Malkani, S., Chung, P. and Moody, T. W. (1998) Non-small cell lung cancer cycloxygenase activity and proliferation are inhibited by non-steroidal antiinflammatory drugs. Anticancer Res. 18, 775-782.

Kinzler, A. K. and Vogelstein, B. (1998) Colorectal tumors; in: The genetic basis of human cancer, Vogelstein, B. and Kinzler, K. W. (eds.), pp. 565-587. McGraw-Hill, New York, USA.

Kundu, N., Smyth, M. J., Samsel, L. and Fulton, A. M. (2002) Cyclooxygenase inhibitors block cell growth, increase ceramide and inhibit cell cycle. Breast Cancer Res. Treat. 76, 57-64.

Lahm, H., Andre, S., Hoeflich, A., Fischer, J. R., Sordat, B., Kaltner, H., Wolf, E. and Gabius, H. J. (2001) Comprehensive galectin fingerprinting in a panel of 61 human tumor cell lines by RT-PCR and its implications for diagnostic and therapeutic procedures. J. Cancer Res. Clin. Oncol. 127, 375-386.

Liu, F. T., Patterson, R. J. and Wang, J. L. (2002) Intracellular functions of galectins. Biochim. Biophys. Acta. 1572, 263-273.

Lundholm, K., Gelin, J., Hyltander, A., Lonnroth, C., Sandstrom, R., Svaninger, G., Korner, U., Gulich, M., Karrefors, I. and Norli, B. (1994) Anti-inflammatory treatment may prolong survival in undernourished patients with metastatic solid tumors. Cancer Res. 54, 5602-5606.

Panje, W. R. (1981) Regression of head and neck carcinoma with a prostaglandin-synthesis inhibitor. Arch. Otolaryngol. 107, 658-663.

Pelzmann, M., Thurnher, D., Gedlicka, C., Martinek, H. and Knerer, B. (2004) Nimesulide and indomethacin induce apoptosis in head and neck cancer cells. J. Oral Pathol. Med. 33, 607-613.

Perillo, N. L., Marcus, M. E. and Baum, L. G. (1998) Galectins: Versatile modulators of cell adhesion, cell proliferation, and cell death. J. Mol. Med. 76, 402-412.

Perillo, N. L., Pace, K. E., Seilhamer, J. J. and Baum, L. G. (1995) Apoptosis of T cells mediated by galectin-1. Nature 378, 736-739.

Rabinovich, G. A., Baum, L. G., Tinari, N., Paganelli, R., Natoli, C., Liu, F. T. and Iacobelli, S. (2002) Galectins and their ligands: amplifiers, silencers or tuners of the inflammatory response? Trends Immunol. 23, 313-320.

Rubinstein, N., Alvarez, M. and Zwirner, N. W. (2004) Targeted inhibition of galectin-1 gene expression in tumor cells results in heightened $\mathrm{T}$ cell-mediated rejection: A potential mechanism of tumor-immune privilege. Cancer Cell. 5, 241-251.

Sanjuan, X., Fernandez, P. L., Castells, A., Castronovo, V., van den Brule, F., Liu, F. T., Cardesa, A. and Campo, E. (1997) Differential expression of galectin 3 and galectin 1 in colorectal cancer progression. Gastroenterology 113, 1906-1915.

Sawaoka, H., Kawano, S., Tsuji, S., Tsujii, M., Murata, H. and Hori, M. (1998) Effects of NSAIDs on proliferation of gastric cancer cells in vitro: Possible implication of cyclooxygenase-2 in cancer development. J. Clin. Gastroenterology 27, 47-52.

Smith, M. L., Hawcroft, G., Hull and M. A. (2000) Effect of nonsteroidal anti-inflammatory drugs on human colorectal cancer cells: Evidence of differant mechanisms of action. Eur. J. Cancer 36, 664-674. 
Sonnenberg, A. and Fennerty, M. B. (2003) Medical decision analysis of chemoprevention against esophageal adenocarcinoma. Gastroenterology 124, 1758-1766.

Stevenson, M. A., Zhao, M. J., Asea, A., Coleman, C. N. and Calderwood, S. K. (1999) Salicylic acid and aspirin inhibit the activity of RSK2 kinase and repress RSK2-depedent transcription of cyclic AMP response element binding protein and NF- $\mathrm{BB}$ responsive genes. J. Immunol. 163, 5608-5616.

Waddell, W. R. and Gerner, R. E. (1980) Indomethacin and ascorbate inhibit desmoid tumors. J. Surg. Oncol. 15, 85-90.

Wang, H. M. and Zhang, G. Y. (2005) Indomethacin suppresses growth of colon cancer via inhibition of angiogenesis in vivo.
World J. Gastroenterol. 11, 340-343.

Williams, C. S., Watson, A. J., Sheng, H., Helou, R., Shao, J. and DuBois, R. N. (2000) Celecoxib prevents tumor growth in vivo without toxicity to normal gut: Lack of correlation between in vitro and in vivo models. Cancer Res. 60, 6045-6051.

Yang, R. Y. and Liu, F. T. (2003) Galectins in cell growth and apoptosis. Cell Mol. Life Sci. 60, 267-276.

Zhang, X., Morham, S. G., Langenbach, R. and Young, D. A. (1999) Malignant transformation and anti-neoplastic action of nonsteroidal anti-inflammatory drugs (NSAIDs) on cyclooxygenasenull embryo fibroblasts. J. Exp. Med. 190, 451-459. 